\title{
Regulation of DNA Damage Following Termination of Hedgehog (HH) Survival Signaling at the level of the GLI Genes in Human Colon Cancer
}

\author{
Akwasi Agyeman'1, Tapati Mazumdar ${ }^{1}$, and Janet A. Houghton ${ }^{1}$ \\ ${ }^{1}$ Department of Cancer Biology, Lerner Research Institute, Cleveland Clinic, Cleveland, $\mathrm{OH}$ \\ Correspondence to:Janet A. Houghton, email: houghtj@ccf.org \\ Keywords: Hedgehog, GLI1/GLI2 inhibition, GANT61, DNA damage, colon cancer \\ Received: August 03, 2012, Accepted: August 18, 2012, Published: August 20, 2012
}

Copyright: ( $)$ Agyeman et al. This is an open-access article distributed under the terms of the Creative Commons Attribution License, which permits unrestricted use, distribution, and reproduction in any medium, provided the original author and source are credited.

\section{ABSTRACT:}

Transcriptional regulation of the Hedgehog $(\mathrm{HH})$ signaling response is mediated by GLI genes (GLI1, GLI2) downstream of SMO, that are also activated by oncogenic signaling pathways. We have demonstrated the importance of targeting GLI downstream of SMO in the induction of cell death in human colon carcinoma cells. In HT29 cells inhibition of GLI1/GLI2 by the small molecule inhibitor GANT61 induced DNA double strand breaks (DSBs) and activation of ATM, MDC1 and NBS1; YH2AX and MDC1, NBS1 and MDC1 co-localized in nuclear foci. Early activation of ATM was

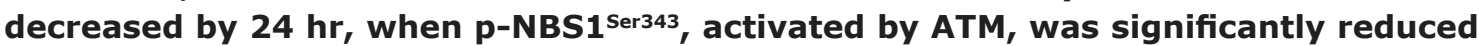
in cell extracts. Bound YH2AX was detected in isolated chromatin fractions or nuclei during DNA damage but not during DNA repair. MDC1 was tightly bound to chromatin at $32 \mathrm{hr}$ as cells accumulated in early S-phase prior to becoming subG1, and during DNA repair. Limited binding of NBS1 was detected at all times during DNA damage but was strongly bound during DNA repair. Transient overexpression of NBS1 protected HT29 cells from GANT61-induced cell death, while knockdown of H2AX by H2AXshRNA delayed DNA damage signaling. Data demonstrate following GLI1/GLI2 inhibition: 1) induction of DNA damage in cells that are also resistant to SMO inhibitors, 2) dynamic interactions between YH2AX, MDC1 and NBS1 in single cell nuclei and in isolated chromatin fractions, 3 ) expression and chromatin binding properties of key mediator proteins that mark DNA damage or DNA repair, and 4) the importance of NBS1 in the DNA damage response mechanism.

\section{INTRODUCTION}

Canonical $\mathrm{HH}$ signaling engages the transmembrane receptor $\mathrm{PTCH}$, the intermediary signaling molecule $\mathrm{SMO}$, and the transcriptional regulators of the $\mathrm{HH}$ signaling response, GLI. In normal cellular processes, regulation by $\mathrm{HH}$ is involved in embryogenesis, tissue patterning, stem cell function, and differentiation $[1,2]$. The GLI genes comprise a family of transcription factors that transcriptionally regulate downstream targets in HH-dependent survival. GLI2 appears to be the primary activator of $\mathrm{HH}$ signaling, with GLI1 as a transcriptional target of GLI2, which may amplify HH-induced, GLI2mediated transcription of GLI1 target genes [1, 3-5]; GLI1 and GLI2 induce transcription of overlapping and distinct sets of target genes [1,3-6], their cooperative roles are critical in $\mathrm{HH}$-dependent survival signaling while their specific roles have been defined only partially [7]. $\mathrm{GLI}^{-/-}$mice have no obvious phenotype [5], in contrast to homozygous GLI2 ${ }^{-/}$mice which die at birth $[6,8]$, indicating the critical role of cooperative GLI function in gene regulation and survival.

Dysregulated canonical HH signaling is part of the malignant phenotype of several types of human cancers. Thus, amplification of GLI1 or GLI2, mutations in PTCH or SMO, aberrant gene expression, or upregulated expression of HH ligands, have been identified [1,7]. Small molecule inhibitors of SMO upstream of GLI have been investigated in preclinical models [9-15], and in the treatment of various types of cancers in humans [14, 1618]. Those tumors sensitive to SMO inhibitors including basal cell carcinoma $[19,20]$ and medulloblastoma $[16$, 
21] rely on canonical $\mathrm{HH}$ signaling for survival. In other cancer types, SMO inhibitors have demonstrated limited clinical activity (GDC-0449, IPI-926, LDE225; reviewed in $[14,16])$. Intrinsic resistance to these agents is frequent $[9,14,16-18,22]$, and acquired resistance to GDC-0449 following initial response by mutation of SMO has been reported in medulloblastoma [23]. In colon cancer, activation of the $\mathrm{HH}$ pathway progresses during carcinogenesis and in metastatic disease [11, 24, 25], and is activated in human colon carcinoma cell lines [26, 27] and xenograft models [11], by ligand-dependent and ligand-independent mechanisms. Canonical HH signaling is linked to genomic instability involving inactivation of DNA repair mechanisms, defects in checkpoint activation, and predisposition to development of cancers [28-30]. Chromosome instability is a hallmark of colon cancer, resulting primarily from deregulation of the DNA replication and mitotic spindle checkpoints (reviewed in [31]). We have demonstrated that $\mathrm{HH}$ signaling is a critical determinant of cell survival in colon cancer following inhibition of the pathway at the level of the GLI genes downstream of SMO [26, 27, 32, 33]. Non-canonical, oncogene-driven signaling pathways, including activation of the RAS/RAF pathway by genetic mutations in colon cancer, converge on the activation of GLI genes and their downstream targets [7, 22, 34, 35]. Reduced GLI activity in response to the RAS/RAF/MEK/ERK signaling inhibitor U0126 [36, 37] was demonstrated in HT29 cells [33] (mutated B-RAF V600E [38]). This emphasizes that switching off the GLI genes downstream of SMO, that determines $\mathrm{HH}$-dependent transcriptional gene regulation, is critical in terminating $\mathrm{HH}$-dependent survival in cancer cells.

In contrast to $\mathrm{SMO}$, few agents are available that can specifically probe the role of GLI in cell survival. GANT61 was identified in a cell-based screen for small molecule inhibitors of GLI1-mediated transcription. In the original study [39], GANT61 abrogated GLI function in the nucleus, blocked both GLI1- and GLI2- mediated transcription, and inhibited GLI1-DNA binding. We further demonstrated [32] the specificity of GANT61 for GLI1 and GLI2, rapid inhibition of GLI binding to target gene promoters in ChIP analyses, reduced GLIluciferase activity, and inhibition of transcriptional

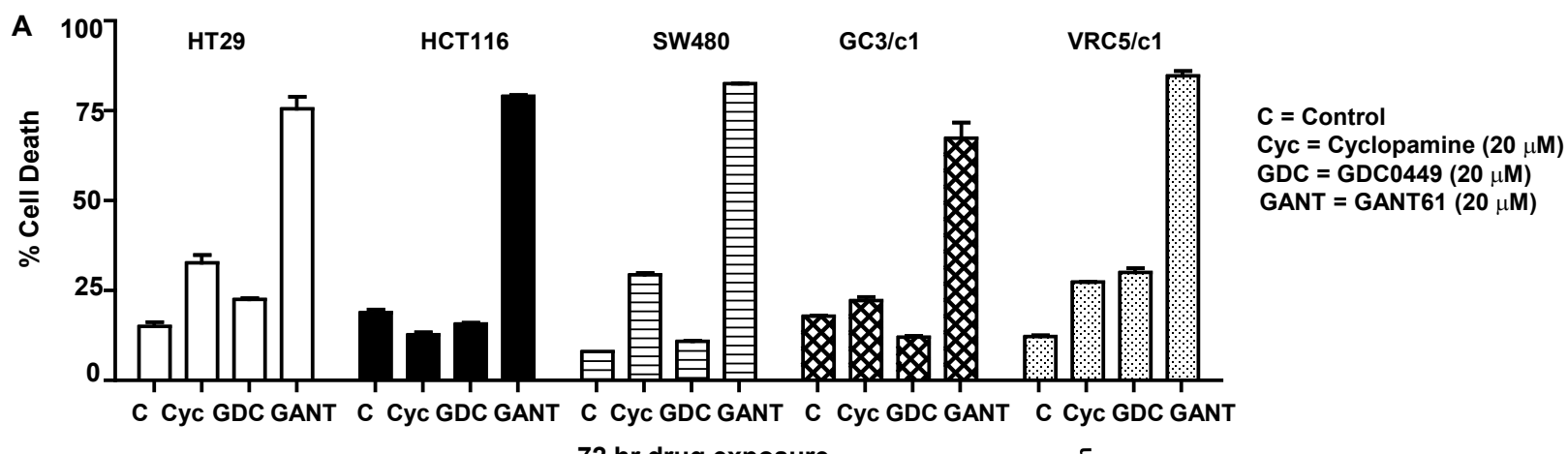
$72 \mathrm{hr}$ drug exposure
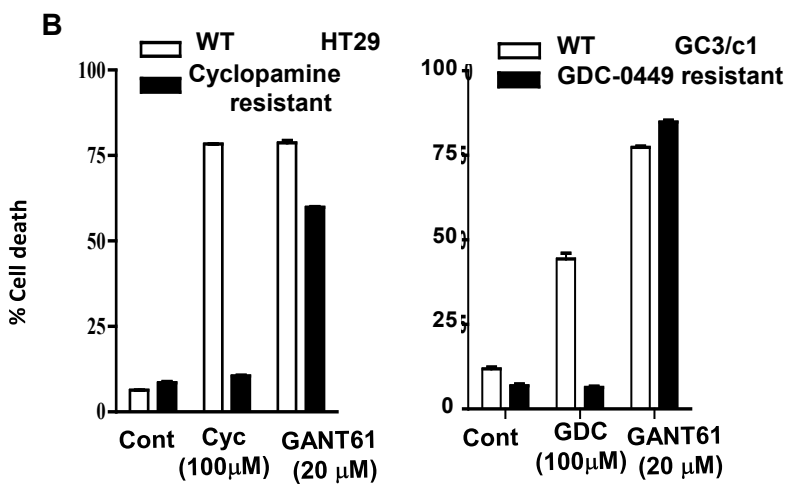

$72 \mathrm{hr}$ drug exposure

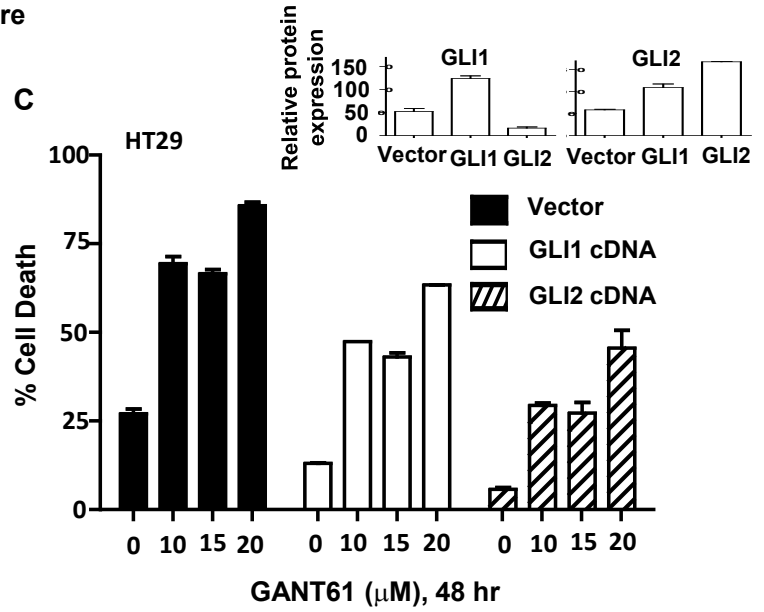

Figure 1: GLI is the critical target in switching off HH survival signaling. A: HT29 cells were treated with equimolar concentrations of GANT61 $(20 \mu \mathrm{M})$, cyclopamine $(20 \mu \mathrm{M})$ or GDC-0449 $(20 \mu \mathrm{M})$ for $72 \mathrm{hr}$. The extent of cell death was determined at the end of drug exposure. B: HT29 or GC3/c1 cells were selected for resistance to cyclopamine or GDC-0449, respectively, by stepwise selection in increasing drug concentrations from $20 \mu \mathrm{M}$ to $100 \mu \mathrm{M}$. Sensitivity of resistant cells to cyclopamine (100 $\mu \mathrm{M})$, GDC-0449 $(100 \mu \mathrm{M})$ or GANT61 $(20 \mu \mathrm{M})$ was examined after $72 \mathrm{hr}$ drug exposure. C: HT29 cells overexpressing GLI1cDNA or GLI2cDNA were examined for their sensitivity to GANT61 at increasing concentrations of $10 \mu \mathrm{M}, 15 \mu \mathrm{M}$ and $20 \mu \mathrm{M}$ for 48 hr. Percent cell death was determined. Inset: Relative expression of GLI1 and GLI2 in HT29 cells overexpressing GLI1 (left) or GLI2 (right). Cell death was determined by Annexin V FITC/PI staining and FACS analysis. Data represent the mean +/- SD, n=2. 
regulation of target genes after $1 \mathrm{hr}$ exposure to GANT61. A third member of the GLI family, GLI3, is expressed as a cleaved C-terminally truncated form (GLI3R) that silences HH-GLI targets in developmental regulation and embryogenesis [11, 40]. Transient expression of GLI3R repressed GLI1 and GLI2 transcriptional activity in colon cancer cell lines, paralleling the effects of GANT61 [32, 33]. GLI3R transfection not only reduced expression and switched off the function of GLI1 and GLI2, but also induced DNA double strand breaks (DSBs) marked by H2AX nuclear foci, and induced cell death [32]. Following the induction of DNA damage, colon cancer cells accumulated in early S-phase without further progression before becoming subG1 [27]. cDNA microarray gene profiling demonstrated reduced expression of genes engaged in DNA replication, DNA damage signaling, and DNA repair at the G1/S interface [26].

In response to DNA damage, DSBs activate ATM-

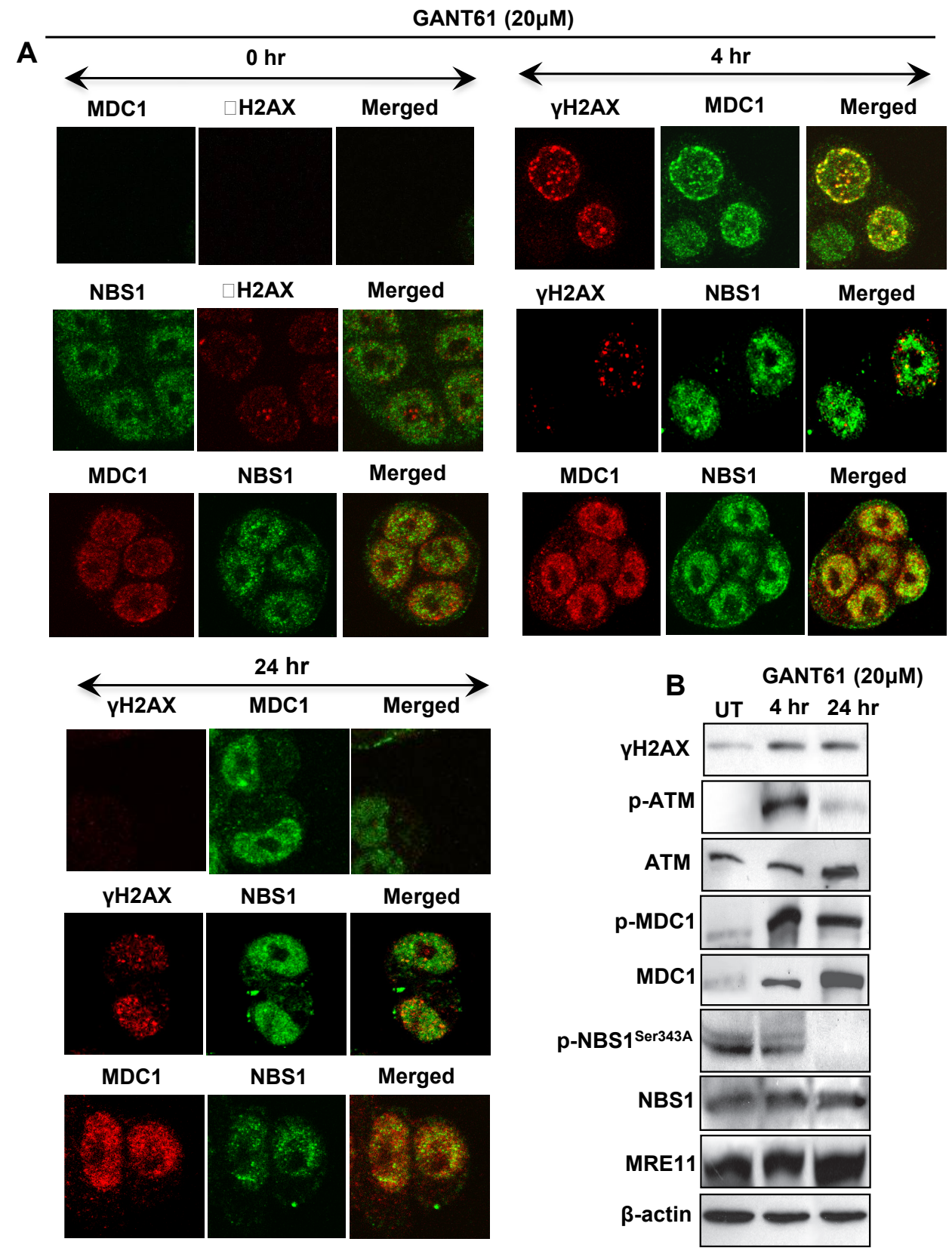

Figure 2: Expression of DNA damage-induced mediator proteins at 4 hr and 24 hr in HT29 cells following inhibition of GLI1/GLI2 by GANT61 (20 $\boldsymbol{\mu M})$. A: Localization of $\gamma \mathrm{H} 2 \mathrm{AX}$, MDC1 and NBS1 nuclear foci in single cells and their co-localization was determined after GANT61 administration. After cells were fixed, permeabilized, treated with the respective antibodies, and stained, four-color image acquisition was performed by confocal microscopy and post-processing analysis of the images was as described in Materials and Methods. B: Western analysis of the expression of total and activated forms $\left(\gamma \mathrm{H} 2 \mathrm{AX}, \mathrm{p}-\mathrm{ATM}, \mathrm{p}-\mathrm{MDC} 1, \mathrm{p}-\mathrm{NBS} 1^{\mathrm{Ser} 343}\right)$ of mediator proteins was examined after treatment of HT29 cells with GANT61. 
dependent phosphorylation of $\mathrm{H} 2 \mathrm{AX}, \mathrm{MDC} 1$, and NBS1. ATM phosphorylates the carboxy-terminal tail of histone $\mathrm{H} 2 \mathrm{AX}$ in the vicinity of the break $[41,42,43]$. This chromatin modification is crucial for the relocalization of proteins to sites flanking DSBs, and generates foci required to promote efficient repair and sustained DNA damage signaling $[44,45]$. MDC1 colocalizes with $\gamma \mathrm{H} 2 \mathrm{AX}$ by direct interaction between the C-terminal twin BRCT domains of MDC1 and the $\gamma \mathrm{H} 2 \mathrm{AX}$ phosphoepitope $[46,47]$. MDC1 also recruits mediators of DNA repair including NBS1 to DNA double strand break sites, and is crucial in nuclear foci to promote sustained DNA damage signaling and repair [41, 46, 47,48, 49]. NBS1 activity in early S-phase is critical for regulation of DNA replication, activation of the intra-S-phase checkpoint, and repair of DNA DSBs [49-52,53-56]. NBS1 functions in the evolutionarily conserved MRN (MRE11-RAD50NBS1) complex in signaling of DSBs within chromatin, in activity at replication forks, and in DNA repair [55-57]. In response to DNA damage, MRN regulates the activity of ATM by direct binding to NBS1 through a C-terminal motif, recruiting ATM to the vicinity of DNA DSBs and stimulating ATM activation [55, 57]. ATM-dependent phosphorylation of NBS1, which occurs at $\mathrm{Ser}^{343}$, is then necessary for activation of the MRN complex, localization of MRN to the nucleus, and for recruitment to DNA break sites for repair of damaged DNA [49, 55, 57]. MRE11, which binds at the C-terminus of NBS1, also binds to DNA and provides endonucleolytic activities for DNA processing [57-59]. The MDC1-NBS1 interaction is crucial for the targeting and retention of NBS1 on chromatin flanking DNA DSBs. Following DNA damage signaling, the recognition and processing of DNA damage occur at the onset of S-phase [32, 60].

Using GANT61, cyclopamine and GDC-0449 we have demonstrated the importance of targeting GLI downstream of SMO in termination of $\mathrm{HH}$ survival signaling that leads to the induction of cell death in human colon carcinoma cells. Data demonstrate that colon cancer cells resistant to cyclopamine or GDC-0449 remain sensitive to GANT61. Inhibition of GLI1/GLI2 by the small molecule inhibitor GANT61 induces DNA DSBs marked by $\gamma \mathrm{H} 2 \mathrm{AX}$ nuclear foci, an ATM-dependent DNA damage signaling mechanism, and activation of MDC1 and NBS1. We have developed a model of DNA damage and DNA repair using GANT61 and explored the mechanisms downstream of GLI1/GLI2 inhibition. Using this model, we have identified the dynamic interactions of the DSB signaling components $\gamma \mathrm{H} 2 \mathrm{AX}, \mathrm{MDC} 1$ and NBS1 at the level of chromatin in DNA damage signaling upstream of cell death, or in DNA repair. Further, data demonstrate the importance of NBS1 in the outcome of the DNA damage response, following termination of $\mathrm{HH}$ survival signaling at the level of GLI, in human colon carcinoma cells.
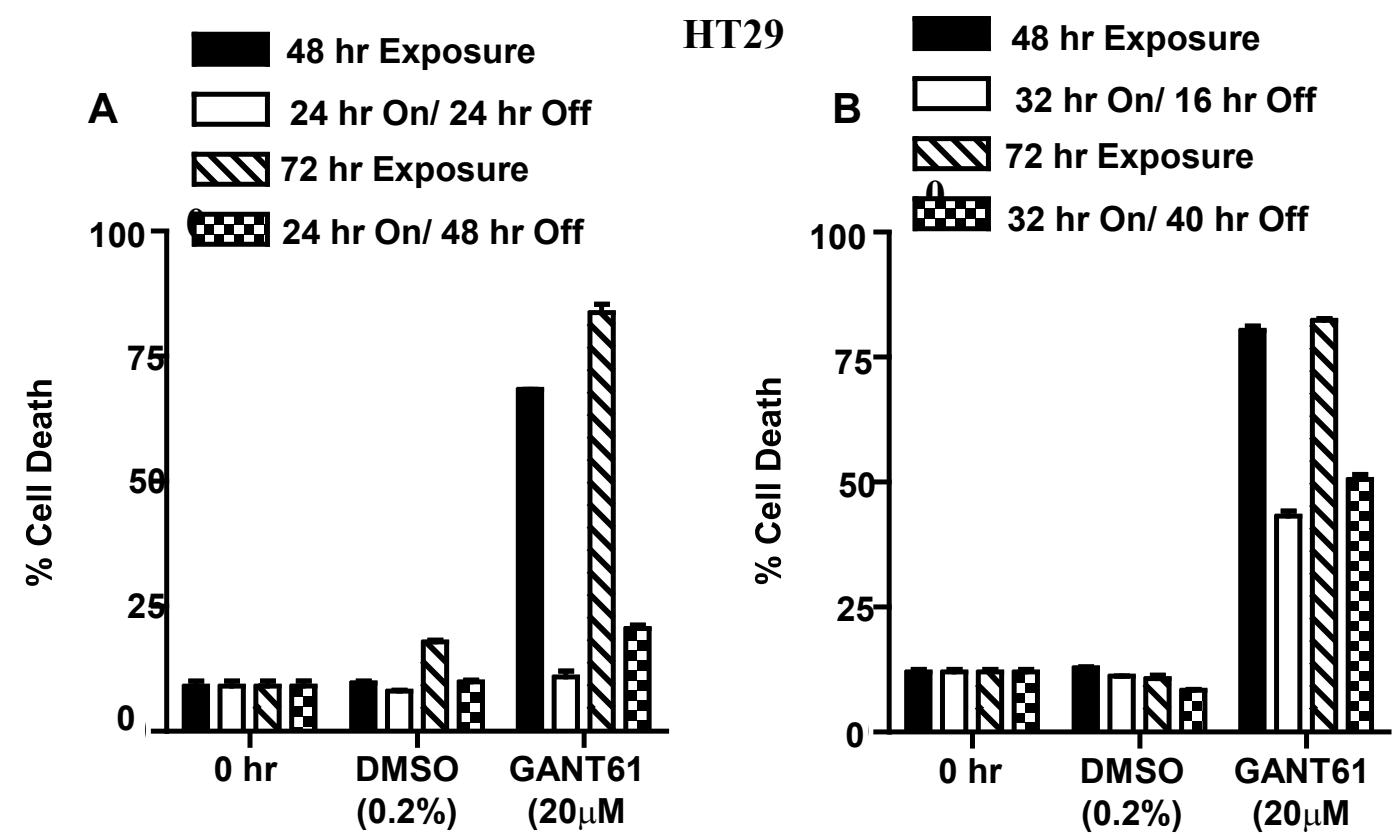

Figure 3: Model of DNA damage and DNA repair in HT29 cells following GLI1/GLI2 inhibition. A,B: DNA damage: HT29 cells treated with GANT61 $(20 \mu \mathrm{M})$ for $48 \mathrm{hr}$ or $72 \mathrm{hr}$ continuous exposure undergo DNA damage upstream of cell death. A: DNA repair: Cells exposed to GANT61 for $24 \mathrm{hr}$ (which induces DNA damage) followed by placing in drug-free medium for $24 \mathrm{hr}$ or $48 \mathrm{hr}$ can be rescued during which time they repair damaged DNA. B: Cells exposed to GANT61 $(20 \mu \mathrm{M})$ for $32 \mathrm{hr}$ followed by placing in drug-free medium for a further $16 \mathrm{hr}$ or $40 \mathrm{hr}$ can only be partially rescued from cell death. Cell death was determined by Annexin V FITC/PI staining and FACS analysis. Data represent the mean $+/-\mathrm{SD}, \mathrm{n}=2$. 


\section{RESULTS}

Switching off HH signaling at the level of GLI induces extensive cell death in contrast to targeting SMO upstream of GLI:

HT29, HCT116, SW480, GC3/c1 and VRC5/c1 cells were exposed to GANT61 (GLI antagonist), the classic SMO antagonist cyclopamine, or the clinically used SMO inhibitor, GDC-0449, for $72 \mathrm{hr}$, and their relative efficacies compared at equimolar drug concentrations (20 $\mu \mathrm{M}$; Figure 1A). Minimal cell death $(<35 \%)$ determined by Annexin V/PI staining followed by flow cytometry was obtained in the presence of both SMO antagonists. In marked contrast, GANT61-induced GLI inhibition caused $>85 \%$ cell death in all cell lines. To further determine the importance of $\mathrm{HH}$ signaling regulation at the level of GLI in cell survival, HT29 or GC3/c1 cells were selected for high-level resistance to cyclopamine or GDC-0449, respectively, at 5-fold higher, supra-physiologic drug concentrations $(100 \mu \mathrm{M})$. Both HT29 and GC3/c1 cells resistant to SMO inhibitors maintained the high degree of sensitivity to GANT61 (20 $\mu$ M; Figure 1B). Further, HT29 cells stably overexpressing GLI1 or GLI2 demonstrated reduced sensitivity to GANT61 at all concentrations up to $20 \mu \mathrm{M}$ examined (Figure 1C).

NBS1 co-localizes with MDC1 and not $\gamma \mathrm{H2AX}$ in nuclear foci; p-NBS1Ser343 is lost from cell extracts following GLI1/GLI2 inhibition:

HT29 cells were treated for $4 \mathrm{hr}$ or $24 \mathrm{hr}$ with GANT61 $(20 \mu \mathrm{M})$. Cells were analyzed by confocal microscopy to determine the subcellular localization of $\gamma \mathrm{H} 2 \mathrm{AX}, \mathrm{MDC} 1$ and NBS1 in cells and in nuclear foci during the induction of early DNA damage at 4 $\mathrm{hr}$ [33], and at the G1/S boundary at $24 \mathrm{hr}$ when cells were accumulating in early $\mathrm{S}[26,32,33]$ (Figure 2A). Alternatively, cells were harvested for western analysis (Figure 2B). Examination at the single cell level revealed $\gamma \mathrm{H} 2 \mathrm{AX}$ nuclear foci at $4 \mathrm{hr}$ after GANT61 exposure that were increased in intensity and frequency at $24 \mathrm{hr}$. MDC1 nuclear foci were also detected at $4 \mathrm{hr}$ and $24 \mathrm{hr}$ following GANT61 and co-localized with $\gamma \mathrm{H} 2 \mathrm{AX}$. In contrast, NBS1 nuclear foci did not co-localize with H2AX, but were superimposable with MDC1 foci (Figure 2A). Western analysis of HT29 cells at the same time points following GANT61 exposure revealed activation of ATM at $4 \mathrm{hr}$, that was significantly reduced by $24 \mathrm{hr}$. MDC1
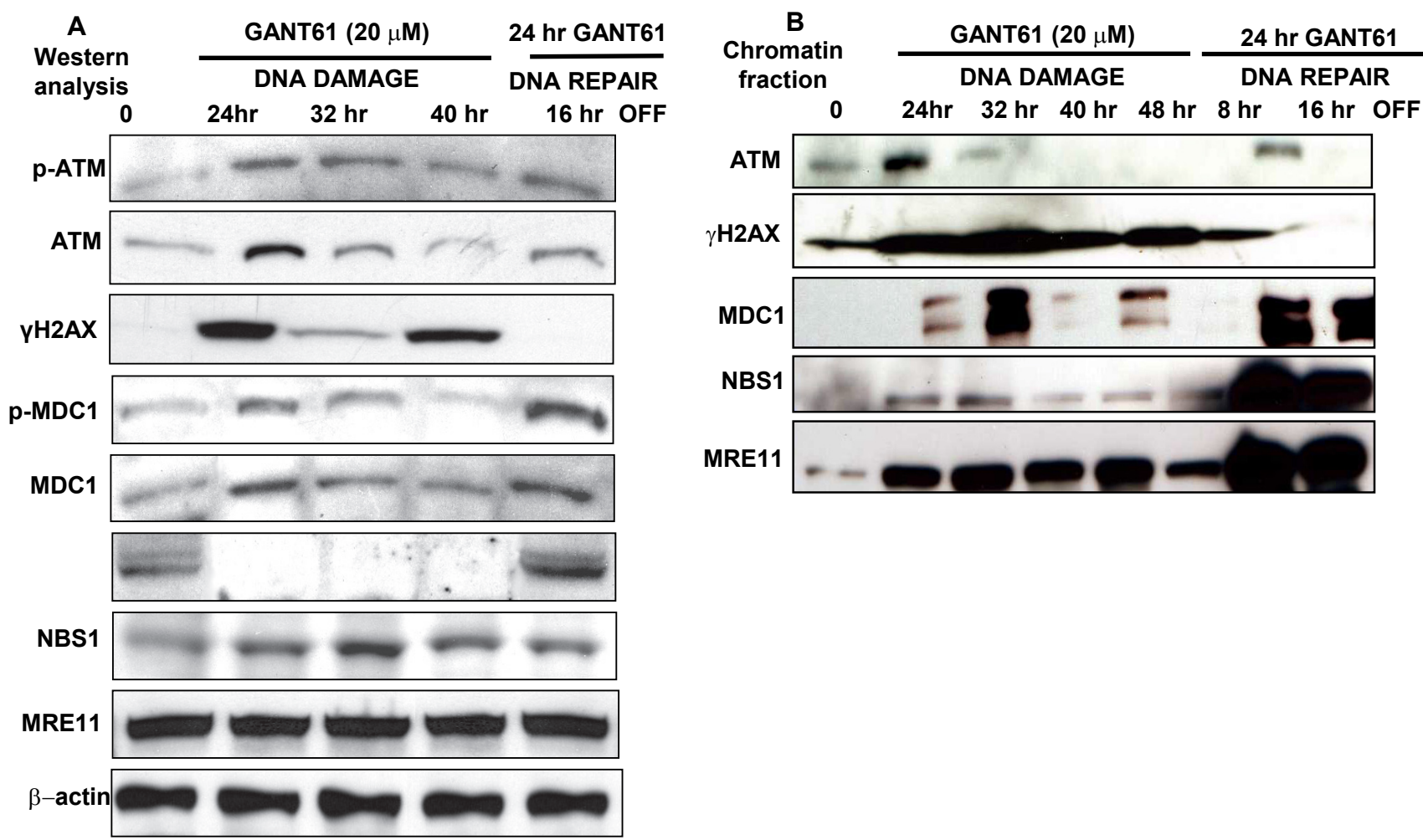

Figure 4: A: The expression of DNA damage-induced mediator proteins was examined following GLI1/GLI2 inhibition for up to $48 \mathrm{hr}$ during continuous exposure to GANT61 (20 $\mu \mathrm{M}$; DNA damage) or during DNA repair following 24 hr exposure to GANT61 $(20 \mu \mathrm{M})$ and $16 \mathrm{hr}$ rescue in drug-free medium. A: Western analysis. $\beta$-actin was used as the loading control. B: Binding of mediator proteins to chromatin following chromatin extraction and western analysis from GANT61-treated HT29 cells as described in Materials and Methods. 
was activated at both $4 \mathrm{hr}$ and $24 \mathrm{hr}$. Similar to p-ATM, p-NBS1 $1^{\text {Ser343 }}$, phosphorylated by ATM, was present at 4 $\mathrm{hr}$ but was significantly reduced in cell extracts at $24 \mathrm{hr}$ (Figure 2B).

\section{Model of DNA damage and DNA repair:}

To elucidate the mechanisms that influence DNA damage or DNA repair following GLI1/GLI2 inhibition, a model was established in HT29 cells following GANT61 treatment. HT29 cells continuously exposed to GANT61 $(20 \mu \mathrm{M})$ for $\geq 48 \mathrm{hr}$ undergo DNA damage upstream of cell death (Figure 3). However cells exposed to GANT61 for $24 \mathrm{hr}$ that induces DNA damage can be rescued by placing in drug-free medium, following which time DNA is repaired (Figure 3A). When GANT61 $(20 \mu \mathrm{M})$ exposure is increased from $24 \mathrm{hr}$ to $32 \mathrm{hr}$, the ability to fully rescue from GANT61-induced cell death is lost (Figure 3B). Continuous exposure to GANT61, or $24 \mathrm{hr}$ exposure with washout were subsequently used to model DNA damage and DNA repair, respectively.
Expression of DNA damage signaling molecules during DNA damage and DNA repair:

Expression of p-ATM and total ATM, $\gamma \mathrm{H} 2 \mathrm{AX}$,

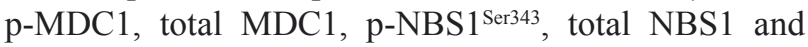
MRE11, was examined during DNA damage or during DNA repair in HT29 cells following GANT61 exposure $(20 \mu \mathrm{M})$. Protein expression was examined for up to 40 hr of continuous exposure to GANT61 (DNA damage), or alternatively following $24 \mathrm{hr}$ GANT61 exposure with a 16 hr washout to allow cells to undergo DNA repair (Figure 4A). Total ATM was expressed at each time point, being more prominent at $24 \mathrm{hr}$ following GANT61 treatment. p-ATM was maintained at the level observed at $24 \mathrm{hr}$, for up to $40 \mathrm{hr}$ examined. $\gamma \mathrm{H} 2 \mathrm{AX}$, marking DNA DSBs, was expressed for up to $40 \mathrm{hr}$, being most prominent at $24 \mathrm{hr}$ and $40 \mathrm{hr}$, however expression in cell extracts disappeared by $16 \mathrm{hr}$ following removal of GANT61. p-MDC1 was detected in cell extracts during the period of DNA damage induced by continuous GANT61 exposure, and expression was significantly increased in the DNA repair phase, while expression of total MDC1 remained relatively constant throughout the experiment. Total NBS1 was present in

\section{Nuclear co-localization of MDC1 and $\gamma \mathrm{H2AX}$ in GANT61-treated HT29 cells}

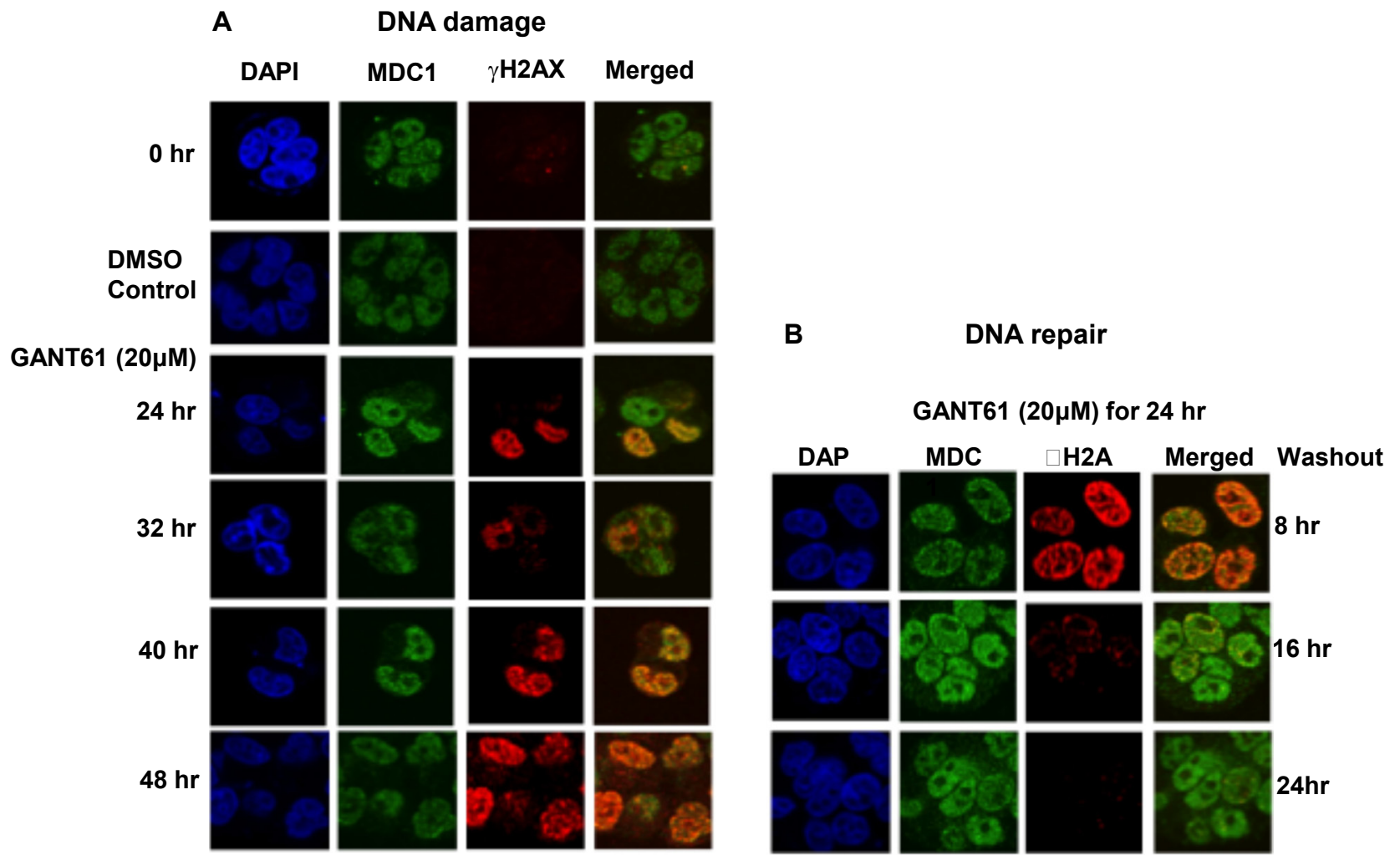

Figure 5: Localization and co-localization of $\gamma \mathrm{H2AX}$ and MDC1 nuclear foci during DNA damage or during DNA repair following GLI1/GLI2 inhibition. A: HT29 cells were treated with GANT61 $(20 \mu \mathrm{M})$ for up to $48 \mathrm{hr}$ (DNA damage), or B: for $24 \mathrm{hr}$ followed by incubation in drug-free medium for $8 \mathrm{hr}, 16 \mathrm{hr}$ or $24 \mathrm{hr}$. $\gamma \mathrm{H} 2 \mathrm{AX}$ and MDC1 nuclear foci were examined by confocal microscopy as described in Materials and Methods and in the legend to Figure 2. 
cell extracts during DNA damage and during DNA repair, however $\mathrm{p}-\mathrm{NBS} 1^{\mathrm{Ser} 343}$ was undetectable after $24 \mathrm{hr}$ during the DNA damage response, but was re-expressed during DNA repair. MRE11 was expressed at a constant level during both DNA damage and repair phases. GANT61 induction of DNA damage that led to cell death thus correlated with the absence of expression of $\mathrm{p}-\mathrm{NBS} 1^{\mathrm{Ser} 343}$ from cell extracts.

Binding of DNA damage signaling molecules to chromatin during DNA damage and DNA repair:

Chromatin was isolated from GANT61-treated $(20 \mu \mathrm{M}) \mathrm{HT} 29$ cells for up to $48 \mathrm{hr}$ during continuous exposure, or at $8 \mathrm{hr}$ and $16 \mathrm{hr}$ following washout after 24 hr exposure (DNA repair; Figure 4B). ATM was tightly bound to chromatin at $24 \mathrm{hr}$ during GANT61 exposure but was decreased at $32 \mathrm{hr}$ and absent from chromatin at $40 \mathrm{hr}$. ATM was bound to chromatin during DNA repair, $16 \mathrm{hr}$ after GANT61 was removed from cells. $\gamma \mathrm{H} 2 \mathrm{AX}$ was highly expressed at all times during the DNA damage response and tightly bound to chromatin, however after GANT61 was removed at $24 \mathrm{hr}$, chromatin-bound $\gamma \mathrm{H} 2 \mathrm{AX}$ was significantly decreased at $8 \mathrm{hr}$, and was almost undetectable bound to chromatin at $16 \mathrm{hr}$ during repair of DNA DSBs. MDC1, critical for retention of NBS1 at the sites of DNA breaks, was highly expressed at $32 \mathrm{hr}$ during the DNA damage response (when cells are arrested in early S [32]) and again during DNA repair, $16 \mathrm{hr}$ after GANT61 was removed from cells. In contrast, NBS1 was only weakly detected bound to chromatin between $24 \mathrm{hr}$ and $48 \mathrm{hr}$ during DNA damage, and was highly chromatin bound during DNA repair (Figure 4B). It should be noted that between $24 \mathrm{hr}$ and $40 \mathrm{hr}$, p-NBS1 ${ }^{\text {Ser343 }}$ was not expressed in cell extracts, but was re-expressed during DNA repair (Figure 4A).

Confocal microscopy of $\gamma \mathrm{H} 2 \mathrm{AX}, \mathrm{MDC} 1$ and NBS1 nuclear foci during DNA damage and DNA repair:

Co-localization of $\gamma \mathrm{H} 2 \mathrm{AX}$ with MDC1 nuclear foci was determined during continuous exposure to GANT61 $(20 \mu \mathrm{M})$ that marked the sites of DNA DSBs, with retention of MDC1 in nuclei. Nuclear foci were determined in expanded time points for up to $48 \mathrm{hr}$ during continuous exposure to GANT61 $(20 \mu \mathrm{M})$ and for up to 24 $\mathrm{hr}$ following removal of drug after a $24 \mathrm{hr}$ exposure (DNA

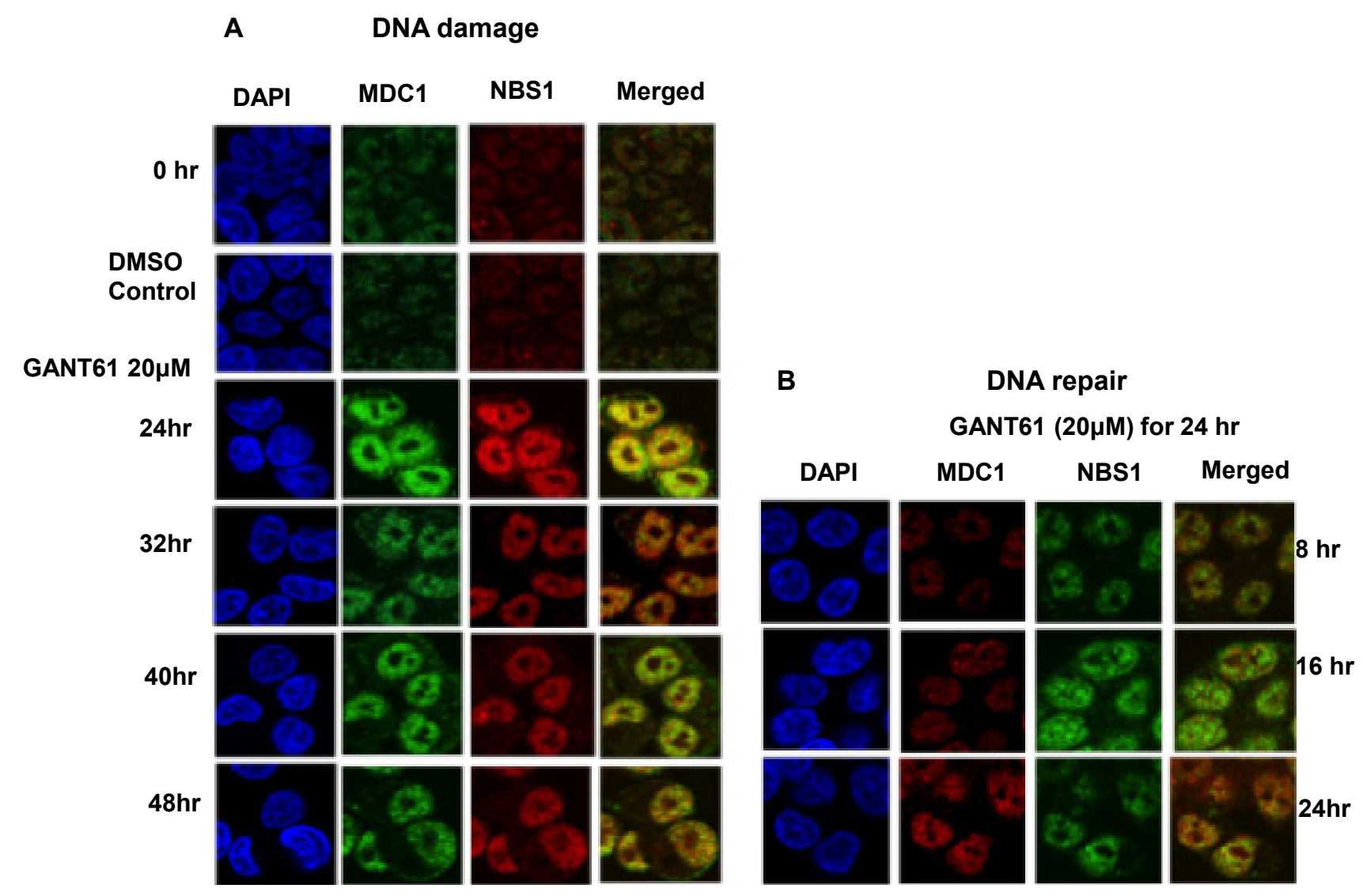

Figure 6: Localization and co-localization of MDC1 and NBS1 nuclear foci during DNA damage or during DNA repair following GLI1/GLI2 inhibition. A: HT29 cells were treated with GANT61 (20 $\mu \mathrm{M})$ for up to $48 \mathrm{hr}$ (DNA damage), or for B: $24 \mathrm{hr}$ followed by incubation in drug-free medium for $8 \mathrm{hr}, 16 \mathrm{hr}$ or $24 \mathrm{hr}$. MDC1 and NBS1 nuclear foci were examined by confocal microscopy as described in Materials and Methods and in the legend to Figure 2. 
repair). MDC1 nuclear foci were detected in untreated cells in contrast to $\gamma \mathrm{H} 2 \mathrm{AX}$ foci which were significantly less frequent (Figure 5A). Both MDC1 and $\gamma \mathrm{H} 2 \mathrm{AX}$ foci were co-localized in nuclei at all times during DNA damage. MDC1 nuclear foci were expressed during DNA repair, correlating with the high degree of binding to chromatin. In contrast, $\gamma \mathrm{H} 2 \mathrm{AX}$ nuclear foci rapidly disappeared from nuclei during DNA repair (Figure 5B), which correlates with the disappearance of $\gamma \mathrm{H} 2 \mathrm{AX}$ from the chromatin fraction during DNA repair. Co-localization of MDC1 and NBS1 nuclear foci was determined at all times for up to $48 \mathrm{hr}$ during continuous exposure to GANT61 (20 $\mu \mathrm{M}$; Figure 6A). During DNA repair, MDC1 and NBS1 nuclear foci were also highly abundant and superimposed, at the same time that $\gamma \mathrm{H} 2 \mathrm{AX}$ foci were disappearing from nuclei and from isolated chromatin (Figure 6B).

\section{Contribution of NBS1 and $\gamma \mathrm{H} 2 \mathrm{AX}$ to the DNA damage response following GLI1/GLI2 inhibition:}

We demonstrated reduced expression of $\mathrm{p}-\mathrm{NBS} 1^{\mathrm{Ser} 343}$ in cell extracts and reduced binding of NBS1 to chromatin during DNA damage under conditions of GLI1/GLI2

A

HT29

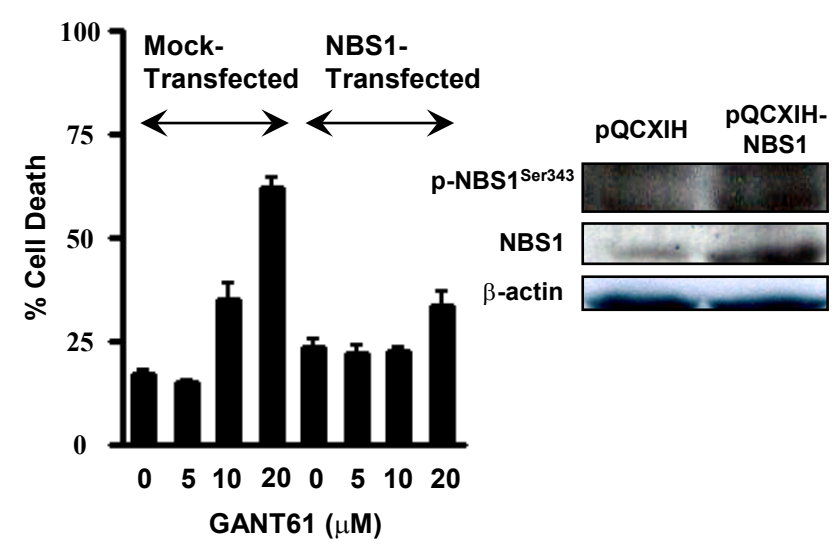

B

\begin{tabular}{|c|c|c|}
\hline Cell death & $\begin{array}{c}\text { Control +/- } \\
\text { SD }\end{array}$ & $\begin{array}{c}\text { GANT61 } \\
+/- \text { SD }\end{array}$ \\
\hline Control & $18.0+/-6.0$ & $80.8+/-1.6$ \\
\hline Nucleoside & $13.8+/-1.0$ & $52.1+/-0.9$ \\
\hline
\end{tabular}

inhibition that led to cell death. Conversely, re-expression of $\mathrm{p}-\mathrm{NBS} 1^{\mathrm{Ser} 343}$ in cell extracts and avid binding of NBS1 to chromatin during DNA repair correlated with rescue from GANT61-induced cell death. To elucidate the role of NBS1 in regulating the outcome of cellular survival downstream of GLI1/GLI2 inhibition, HT29 cells transiently transfected with pQCXIH-NBS1 or mock transfected with vector alone (pQCXIH) for $24 \mathrm{hr}$, were treated for a subsequent $48 \mathrm{hr}$ with GANT61 at varied concentrations from 5-20 $\mu \mathrm{M}$. The influence of NBS1 overexpression on GANT61-induced cell death was determined by Annexin V/PI staining and FACS analysis (Figure 7A). Cell death was inhibited by $30 \%$ at the highest concentration of GANT61 examined, demonstrating the critical role of NBS1 in the DNA damage response that regulates cell death following GLI1/GLI2 inhibition. In addition to total NBS1 overexpression, the expression of the active form of $\mathrm{NBS} 1, \mathrm{p}-\mathrm{NBS} 1^{\mathrm{Ser} 343}$, was also significantly increased (Figure 7A). We also demonstrated that the nucleosides adenosine, guanosine, cytidine and thymidine administered simultaneously at concentrations of $20 \mu \mathrm{M}$, afforded partial protection of HT29 cells from GANT61-induced cell death [27]. Nucleoside rescue from cell death following GLI1/GLI2 inhibition was determined
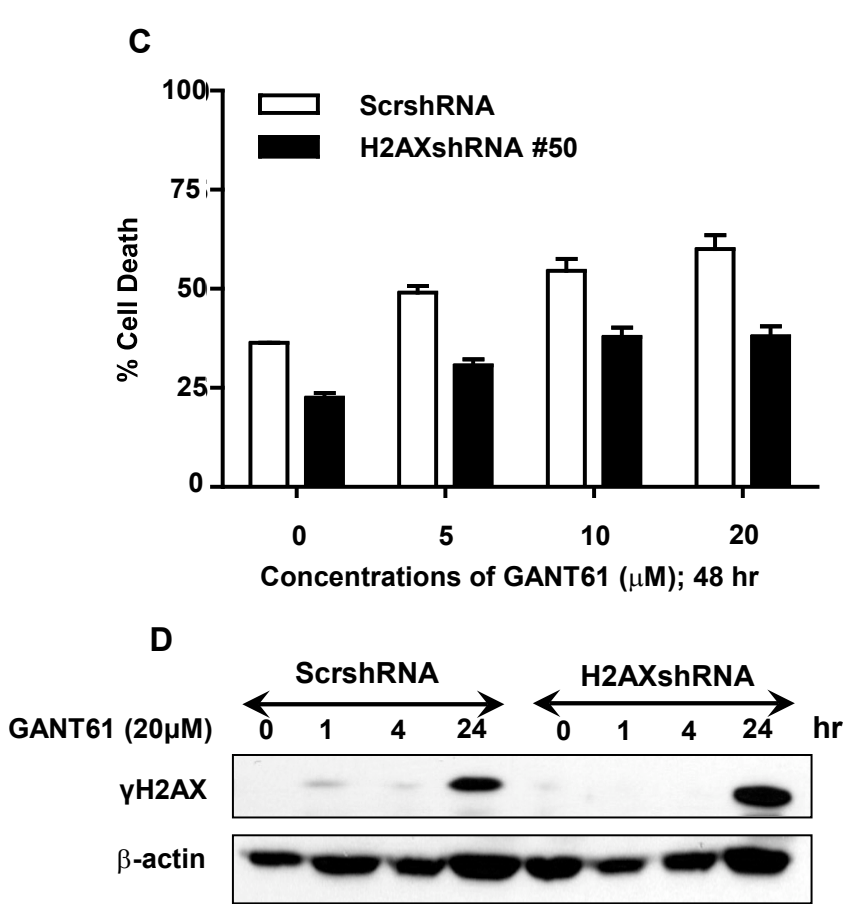

Figure 7: Effect of modulation of NBS1, nucleosides or H2AX during inhibition of HH signaling at the level of GLI. A. In transient transfections, HT29 cells were transfected with the retroviral vector pQCXIH alone, or pQCXIH-NBS1 for 24 hr prior to treatment for $48 \mathrm{hr}$ with GANT61 at concentrations of $0 \mu \mathrm{M}, 5 \mu \mathrm{M}, 10 \mu \mathrm{M}$, or $20 \mu \mathrm{M}$. Cell death was determined. Inset: Total NBS1 and p-NBS1 ${ }^{\text {Ser343 }}$ expression was analyzed by western analysis. B: HT29 cells were treated with $20 \mu \mathrm{M}$ concentrations of each of adenosine, guanosine, cytidine and thymidine simultaneously with GANT61 $(20 \mu \mathrm{M})$ for $72 \mathrm{hr}$, and the extent of cell death determined. C: HT29 cells stably expressing H2AXshRNA or scrambled shRNA were treated with increasing concentrations of GANT61 for 48 hr at which time the extent of cell death was determined. Inset: H2AX knockdown was confirmed by western analysis. D. HT29 cells stably expressing scrambled shRNA or H2AXshRNA were treated with GANT61 $(20 \mu \mathrm{M})$ for up to $24 \mathrm{hr}$, and the expression of $\gamma \mathrm{H} 2 \mathrm{AX}$ determined by western analysis. $\beta$-actin was used as the loading control. 
to be $\approx 30 \%$ (Figure $7 \mathrm{~B}$ ), similar to the protection afforded following transient transfection and overexpression of NBS1. To determine the role of $\gamma \mathrm{H} 2 \mathrm{AX}$ in cell fate following inhibition of GLI1/GLI2 by GANT61, HT29 cells stably expressing H2AXshRNA or scrambled shRNA (ScrshRNA) were treated for $48 \mathrm{hr}$ with GANT61 at doses of $5 \mu \mathrm{M}, 10 \mu \mathrm{M}$ or $20 \mu \mathrm{M}$, and the effect on induction of cell death determined by Annexin V/PI staining and FACS analysis (Figure 7C). Knockdown of H2AX, confirmed by western analysis (Figure $7 \mathrm{C}$ Inset) protected cells from GANT61-induced cell death by $\approx 25 \%$ at $48 \mathrm{hr}$. $\gamma \mathrm{H} 2 \mathrm{AX}$ expression after GANT61 treatment was further examined by western analysis following suppression of $\mathrm{H} 2 \mathrm{AX}$ expression using H2AXshRNA. $\gamma \mathrm{H} 2 \mathrm{AX}$ expression was present in cells transduced with the vector control at $1 \mathrm{hr}$ and $4 \mathrm{hr}$ following GLI1/GLI2 inhibition, but not in cells transduced with H2AXshRNA. Under both conditions $\gamma \mathrm{H} 2 \mathrm{AX}$ expression was present at $24 \mathrm{hr}$. H2AXshRNA transduction and reduction in $\gamma \mathrm{H} 2 \mathrm{AX}$ expression therefore appeared to delay the detection and recognition of DNA damage following GLI1/GLI2 inhibition. This is consistent with reduced $\gamma \mathrm{H} 2 \mathrm{AX}$ binding to chromatin and decreased nuclear $\gamma \mathrm{H} 2 \mathrm{AX}$ foci under conditions of cell rescue following GLI1/GLI2 inhibition, and reduction in cell death.

\section{DISCUSSION}

In this study or previously, we have demonstrated that targeting SMO upstream of GLI using the classic SMO inhibitor cyclopamine [27, 33] (employed extensively in preclinical studies), or the clinically used agent GDC-0449, induces minimal cytotoxicity against cell line models of human colon carcinoma exposed at pharmacologically relevant drug concentrations. In contrast, targeting GLI downstream of SMO using the small molecule inhibitor GANT61, which targets both GLI1 and GLI2 transcription, induces extensive cell death in all of these cell line models at equimolar concentrations $[27,33]$. Similarly, genetic inhibition of GLI1 and GLI2 using the GLI3 repressor, GLI3R, induces DNA damage, $\gamma \mathrm{H} 2 \mathrm{AX}$ expression and nuclear foci, cleavage of caspase-3 and PARP, and cell death, paralleling the effects obtained from pharmacologic targeting of GLI1 and GLI2 [32, 33]. Variable activity of SMO inhibitors has been demonstrated in preclinical models [9-15] and clinically [14, 16-21], in a variety of different types of human cancers. This is due to the predominant dependence of certain types of human cancers on canonical $\mathrm{HH}$ signaling (sensitivity; basal cell carcinoma $[19,20]$, medulloblastoma $[16,21]$ ), or alternatively circumvention of SMO as a therapeutic target in preclinical models and clinically (intrinsic resistance $[9,14,16-18,22])$ due to activation of GLI by alternate non-canonical, oncogenic signaling pathways $[7,22,27,33-35]$. In addition, tumors that are initially sensitive to GDC-0449 can develop acquired resistance to SMO inhibitors following prolonged exposure [23]. In the current study, we selected human colon carcinoma cell lines for resistance to supra-physiological concentrations of cyclopamine or GDC-0449 (100 M), and examined sensitivity of the resistant cell populations to GANT61 $(20 \mu \mathrm{M})$. Under both conditions, cells maintained high degree of sensitivity to the inhibitor of GLI1/GLI2. Further, HT29 cells engineered to overexpress GLI1 or GLI2 demonstrated reduced sensitivity to GANT61. Collectively, data demonstrate the critical importance of the GLI genes in driving cellular survival in colon cancer cells, and that GLI genes may be activated by liganddependent and ligand-independent mechanisms.

Termination of $\mathrm{HH}$ signaling at the level of GLI targeted either by pharmacologic or genetic downregulation induces DNA damage [26, 27, 32, 33], which is recognized in early S-phase [26, 32, 60], and marked by $\gamma \mathrm{H} 2 \mathrm{AX}$ nuclear foci. DNA replication is inhibited in GANT61-treated cells following GLI1/GLI2 inhibition, where genes including thymidylate synthase, thymidine kinase, topoisomerase2, E2F and DNA polymerases are downregulated in expression [26]. The intra-S-phase checkpoint is activated by DNA DSBs and requires ATM [60]. This checkpoint inhibits progression through S-phase, initiation of late origins of replication [61, 62], and stabilizes stalled replication forks [63]. GANT61-treated cells undergo intra-S-phase checkpoint activation at $24 \mathrm{hr}$, characterized by phosphorylation of Cdc25A on Ser123 (which targets this phosphatase for proteasomal degradation), activation of $\mathrm{Cdk} 2$ is inhibited (decreased ${ }^{\text {Tyr15}} \mathrm{p}-\mathrm{Cdk} 2$ ), and cyclin E accumulates [32, 33]. We have previously reported accumulation of HT29 cells in early $\mathrm{S}$ following GLI1/GLI2 inhibition and activation of an intra-S-phase checkpoint that cannot be sustained, with cells becoming subG1 without further progression through S-phase $[32,33]$. In the current study we have identified the molecular interactions between the different signaling molecules involved in DNA damage subsequent to inhibition of GLI1/GLI2 function.

In response to DNA damage, an evolutionarily conserved MRN complex (MRE11, RAD50 and NBS1) regulates the activity of ATM by direct binding of ATM to NBS1, thereby recruiting ATM to the vicinity of DNA DSBs and stimulating ATM activation [55, 57]. NBS1 functions in an evolutionarily conserved complex with MRE11 and RAD50 (MRN) in several cellular contexts including the repair of DNA DSBs (non-homologous end joining, homologous recombination), recognition and signaling of DSBs within chromatin, activity at replication forks [55-57], and is active in early S-phase but not in mid or late S-phase [49-52,53-56]. NBS1 is essential for activation of the intra-S-phase checkpoint in early $\mathrm{S}$ to allow repair of DNA damage $[54,56,57]$. In response to DNA damage, MRN regulates the activity of ATM by direct binding of ATM to NBS1, thereby recruiting ATM to the vicinity of DNA DSBs and stimulating ATM activation 
$[55,57]$. ATM-dependent phosphorylation of NBS1 at Ser343 is then necessary for activation of the MRN complex and for the recruitment of MRN to DNA break sites for repair of damaged DNA[49, 55]. MRN imparts three key functions: 1) DNA binding and processing, 2) DNA tethering to bridge DNA over short and long distances, and 3) activation of the DSB response and checkpoint signaling. NBS1 is essential for localization of MRN to the nucleus and for binding to DNA [57]. MRE11, which binds at the C-terminus of NBS1, and also binds to DNA, provides endonucleolytic activities for DNA processing [57-59]. Finally, RAD50 provides regulatory ATPase and adenlyate kinase activities [57]. NBS1 functions in regulation of MRN activity, where the endogenous concentration of active, phosphorylated NBS1 is a critical regulatory factor [49, 64-67]. Our data demonstrate that upon blocking GLI1/GLI2 activity, DNA damage is induced during which the steady state level of $\mathrm{p}-\mathrm{NBS} 1^{\mathrm{Ser} 343}$ is significantly reduced by $24 \mathrm{hr}$ posttreatment, concurrent with reduced chromatin-associated NBS1 levels. These observations suggest limited NBS1mediated DNA repair events following GANT61-mediated termination of GLI1/GLI2 function. In response to DNA damage, DSBs activate ATM to phosphorylate the carboxy-terminal tail of histone $\mathrm{H} 2 \mathrm{AX}$ in the vicinity of the break [41], a well recognized marker of DNA DSBs $[42,43]$. This chromatin modification is crucial for the relocalization of several proteins to sites flanking DSBs, generating foci that are required to promote efficient repair and sustained DNA damage signaling. MDC1 co-localizes with $\gamma \mathrm{H} 2 \mathrm{AX}[46,47]$, and recruits additional mediators of DNA repair including the MRN complex [48, 49]. Although early reports suggested that the N-terminal FHA-BRCT domains of NBS1 enabled phosphorylationdependent interaction with $\gamma \mathrm{H} 2 \mathrm{AX}$ to retain NBS1 at the sites of DSBs, it now appears that the retention of NBS1 is mediated by binding through a specific region of MDC1 (at residues 219-455) that contains six SDTDXD/E (STD) clusters, and which are constitutively phosphorylated by CK2 in unperturbed cells [47, 56, 68-70]. This MDC1NBS1 interaction via a phospho-dependent mechanism appears crucial for the targeting and retention of NBS1 on chromatin flanking DNA DSBs, and occurs in GANT61induced chromatin modifications, as we have demonstrated by confocal microscopy in human colon carcinoma cells. Thus, NBS1 co-localized in nuclear foci with MDC1 but not $\gamma \mathrm{H} 2 \mathrm{AX}$, and $\gamma \mathrm{H} 2 \mathrm{AX}$ co-localized with MDC1 to facilitate DNA damage signaling. It is evident that $\gamma \mathrm{H} 2 \mathrm{AX}$ and $\mathrm{p}-\mathrm{MDC} 1$ were activated during DNA damage, while p-NBS1 $1^{\text {Ser343 }}$ was significantly decreased in cell extracts by $24 \mathrm{hr}$, in parallel with decreased availability of p-ATM.

We developed a model of DNA damage and DNA repair, where specific mechanisms could be determined in the same model system following GLI1/GLI2 inhibition with GANT61. HT29 cells under continuous GANT61 $(20 \mu \mathrm{M})$ exposure for $48 \mathrm{hr}$ undergo DNA damage that leads to cell death; cells exposed to GANT61 for $24 \mathrm{hr}$ but not $32 \mathrm{hr}$ were rescued by placing in drug-free medium, during which time they repaired damaged DNA. By 32 $\mathrm{hr}$ of continuous GANT61 exposure, cells had arrested in early $\mathrm{S}$ but could not progress [26, 32]. H2AX and p-MDC1 were expressed during continuous GANT61 (20 $\mu \mathrm{M})$ treatment. During DNA repair, $\gamma \mathrm{H} 2 \mathrm{AX}$ expression was significantly reduced, while p-MDC1 expression was increased. Total NBS1 and MRE11 were expressed in GANT61-treated cells during both DNA damage and DNA repair. In contrast, p-NBS1 ${ }^{\text {Ser343 }}$ expression was significantly reduced at $\geq 24 \mathrm{hr}$ during continuous GANT61 exposure, along with lower levels of p-ATM (in comparison to the enhanced activation at $4 \mathrm{hr}$ [32]), but was re-expressed during DNA repair. Upon examination of isolated chromatin fractions from GANT61-treated cells, ATM was highly bound in chromatin fractions at 24 $\mathrm{hr}$ during continuous exposure but not at later times, and at $16 \mathrm{hr}$ during DNA repair. $\gamma \mathrm{H} 2 \mathrm{AX}$ was tightly bound to chromatin during DNA damage, and released during DNA repair. MRE11 was strongly bound to chromatin during DNA damage and during DNA repair. MDC1 was strongly bound to chromatin during the period following GLI1/GLI2 inhibition when cells were accumulated in early S-phase (24 hr, $32 \mathrm{hr}$ [32]), and also during DNA repair when the presence of $\gamma \mathrm{H} 2 \mathrm{AX}$ in chromatin fractions was significantly decreased. However NBS1 binding was limited when cells were undergoing DNA damage, paralleling the loss of $\mathrm{p}-\mathrm{NBS} 1^{\text {Ser343 }}$ from cell extracts, and became strongly bound during DNA repair. The findings obtained for $\gamma \mathrm{H} 2 \mathrm{AX}, \mathrm{MDC} 1$ and NBS1 were confirmed in single cells by confocal microscopy. Thus, co-localization of $\gamma \mathrm{H} 2 \mathrm{AX}$ and $\mathrm{MDC} 1, \mathrm{MDC} 1$ and NBS1, disappearance of $\gamma \mathrm{H} 2 \mathrm{AX}$ as DNA DSBs were repaired after removal of GANT61, with maintenance of NBS1 and MDC1 colocalization, were determined in nuclear foci. Data suggest that $\mathrm{p}-\mathrm{NBS} 1^{\mathrm{Ser} 343}$ required for appropriate intra-S-phase checkpoint formation and sustained activation may be limiting in the processing of DNA damage signaling at the intra-S-phase checkpoint upstream of cell death, following GLI1/GLI2 inhibition.

To further test this hypothesis, HT29 cells were transiently transfected with pQCXIH-NBS1 for $24 \mathrm{hr}$ prior to treatment with varied concentrations of GANT61 (5 $\mu \mathrm{M}, 10 \mu \mathrm{M}, 20 \mu \mathrm{M})$ for $48 \mathrm{hr}$. Overexpression of NBS1 and its activated form, $\mathrm{p}-\mathrm{NBS}^{\mathrm{Ser} 343}$, significantly inhibited GANT61-induced cell death, confirming the critical role of NBS1 in regulating the DNA damage response downstream of GLI1/GLI2 inhibition. This was similar to the protection from DNA damage afforded by nucleosides that rescued cells from GANT61-induced cell death, when DNA replication and key regulatory genes were downregulated [26, 32]. To determine the contribution of $\gamma \mathrm{H} 2 \mathrm{AX}$ to DNA damage signaling upstream of cell death, HT29 cells stably expressing H2AXshRNA were treated with varied concentrations of GANT61 for $48 \mathrm{hr}$. 
Partial decrease in cell death was determined under these conditions, and $\gamma \mathrm{H} 2 \mathrm{AX}$ expression was decreased within the first few hours of GANT61 treatment, but was restored at $24 \mathrm{hr}$. These data together with data derived by western analysis and confocal microscopy suggest that the primary function of $\gamma \mathrm{H} 2 \mathrm{AX}$ is in the recognition of DNA DSBs and in DNA damage signaling, and that suppression of $\mathrm{H} 2 \mathrm{AX}$ expression causes delay in the recognition of DNA damage.

In summary we have demonstrated that the processing of DNA damage following inhibition of $\mathrm{HH}$ signaling at the level of GLI provides a specific rank order of activation of ATM and downstream target genes that recognize DNA damage in early S-phase. The activation of a transient intra-S-phase checkpoint is characterized by limited availability of p-NBS1 $1^{\mathrm{Ser} 343}$ in cell extracts and limited binding of NBS1 to chromatin via MDC1 during the critical phase at which colon carcinoma cells accumulate in early S-phase and attempt to repair damaged DNA. Phosphorylated NBS1 reappears in cell extracts during DNA repair and NBS1 is strongly bound to chromatin via MDC1. The function of $\gamma \mathrm{H} 2 \mathrm{AX}$ appears to be predominantly in the recognition of DNA damage, and in recruitment of MDC1 to sites of DNA breaks marked by $\mathrm{H} 2 \mathrm{AX}$. It is evident that when MDC1 is recruited to $\gamma \mathrm{H} 2 \mathrm{AX}$ DNA break sites, this mediator protein remains bound to chromatin, as does NBS1, while $\gamma \mathrm{H} 2 \mathrm{AX}$ disappears from chromatin when DSBs are repaired. It is evident that the drivers of HH signaling, the GLI genes, are critical to the survival of human colon carcinoma cells, and that DNA damage signaling downstream of GLI1/ GLI2 inhibition is a critical regulator of cell death.

\section{MATERIALS AND METHODS}

\section{Antibodies and Chemicals:}

GANT61 was obtained from Alexis Biochemicals (Farmingdale, NY), cyclopamine from Toronto Research Chemicals (Toronto, ON), and GDC-0449 from JS Research (Boston, MA). Drugs were dissolved in DMSO $(0.2 \%)$ and stored at $-20^{\circ} \mathrm{C}$. Antibodies: Anti-NBS1, anti$\gamma \mathrm{H} 2 \mathrm{AX}$ and anti-Mre11 monoclonal primary antibodies were obtained from Cell Signaling Technology (Danvers, MA). Anti-MDC1 polyclonal antibody and anti-pNBS1 $1^{\text {Ser343 }}$ and p-MDC1 monoclonal antibodies were obtained from Abcam Ltd (Cambridge, MA). Peroxidaseconjugated goat anti-rabbit or goat anti-mouse secondary antibodies were from Santa Cruz Biotechnology (Santa Cruz, CA).

\section{Cell culture and transfections:}

GLI1cDNA, GLI2cDNA, NBS1cDNA and H2AXshRNA transduction: HT29, HCT116 and SW480 cells were obtained from ATCC. GC3/c1 and VRC5/ c1 cells were established in our laboratories from a human colon adenocarcinoma xenograft model [71]. Cell lines were routinely verified by morphology, growth characteristics, and response to cytotoxic agents (Annexin $\mathrm{V} /$ propidium iodide (PI) staining). cDNA microarray gene profiles were also characteristic. Cell lines were verified biannually to be mycoplasma-free. Cells were routinely maintained in the presence of folate-free RPMI 1640 medium containing 10\% dFBS and $80 \mathrm{nM}$ [6RS]5methyltetrahydrofolate. Full length GLI1 and GLI2 delta $\mathrm{N}$ (N-terminus deleted constitutively active mutant; hereon referred to as GLI2) in pBabe-Puro vector were a kind gift from Dr. Graham W. Neill (Barts and The London School of Medicine and Dentistry, Queen Mary University of London). pQCXIH-NBS1 was a kind gift from Dr. Stephen P. Jackson (Cambridge, England). H2AXshRNA and scrambledshRNA in the pGFP-V-RS vector were obtained from Origene (Rockville, MD). GLI1cDNA, GLI2cDNA, H2AXshRNA and ScrshRNA were subcloned into pBabepuro. HT29 cells stably expressing each construct were generated in the presence of a selection antibiotic, puromycin $(1 \mu \mathrm{g} / \mathrm{ml})$ for 2 weeks, and gene expression confirmed. HT29 cells were transiently transfected with pQCXIH-NBS1 or vector control using lipofectamine-2000 following the manufacturer's protocol. At $24 \mathrm{hr}$ post-transfection, cells were treated with varied concentrations of GANT61 (5M, 10M, $20 \mathrm{M}$ ) for $48 \mathrm{hr}$. Cell death was determined by Annexin V/PI staining followed by flow cytometry.

\section{Annexin V/PI staining and flow cytometric analysis:}

Annexin V/PI staining and flow cytometric analysis was performed as described previously [27, 33]. Briefly, cells were treated, in duplicate, as described in the figure legends, after which they were collected by trypsinization and incubated with Annexin V FITC (BD Biosciences) and PI (Sigma) prior to analysis using a FACSCalibur flow cytometer. Raw data were analyzed using CellQuest software.

\section{Western blot analysis:}

Total cellular lysates were prepared using modified RIPA lysis buffer (Cell Signaling Technology, Danvers, MA). Total protein $(54 \mu \mathrm{g})$ from cell lysates was loaded and resolved on $10 \%$ or $5 \%$ SDS-PAGE gels, dependent on protein size. Proteins were transferred onto polyvinylidene 
difluoride membranes, blocked (5\% nonfat dry milk; $1 \mathrm{hr}$ ), washed and incubated with primary antibody overnight at $4^{\circ} \mathrm{C}$, and with secondary antibody for $1 \mathrm{hr}$ and prior to development.

\section{Chromatin isolation:}

HT29 human colon carcinoma cells either mocktreated or treated with GANT61 $(20 \mu \mathrm{M})$ for varying time periods, washed $\mathrm{x} 2$ with ice-cold $1 \times \mathrm{PBS}$, and collected as described [72]. Cell pellets $\left(\approx 2 \times 10^{6}\right.$ cells $)$ were resuspended in $200 \mu \mathrm{l}$ extraction buffer (50 mM Hepes, pH 7.5, $150 \mathrm{mM} \mathrm{NaCl}, 1 \mathrm{mM}$ EDTA, supplemented with $0.1 \%$ Triton $\mathrm{X}-100$, protease inhibitor mixture tablets [Roche Diagnostics] and phosphatase inhibitors [10 $\mathrm{mM} \mathrm{NaF}, 10 \mathrm{mM} \beta$-glycerophosphate, $1 \mathrm{mM}$ sodium orthovanadate, $1 \mathrm{mM}$ cantharidin]; Sigma) for $15 \mathrm{~min}$ on ice for the first extraction. Cells were subsequently centrifuged at 14,000 x g, $3 \mathrm{~min}$, followed by a second extraction on ice for 15 min with $200 \mu$ of fresh extraction buffer. The extract was centrifuged at 14,000 x g, $3 \mathrm{~min}$, $4^{\circ} \mathrm{C}$. The supernatant was pooled with that from the first extraction. The pellet was further incubated in $200 \mu \mathrm{l}$ of extraction buffer without Triton and supplemented with $200 \mu \mathrm{g} / \mathrm{ml}$ RNase A (Sigma, St. Louis, MO) for $30 \mathrm{~min}$ at $25^{\circ} \mathrm{C}$ with agitation. Following centrifugation for $3 \mathrm{~min}$ at $14000 \mathrm{xg}$, the insoluble pellet was resuspended in $1 \mathrm{x}$ PBS containing $1 \% \mathrm{SDS}$ and heated for $10 \mathrm{~min}$ at $100^{\circ} \mathrm{C}$. Samples were sonicated for $10 \mathrm{sec}$ and denaturing loading buffer (60mM Tris-HCl, pH 6.8, 30\% glycerol, 10\% SDS, 0.6M DTT, $0.012 \%$ bromophenol blue) was added to make a $1 \mathrm{x}$ final concentration. Samples were boiled for $5 \mathrm{~min}$ and equal sample volumes of each fraction obtained from equivalent numbers of cells were applied to SDS/PAGE for western blotting.

\section{Confocal microscopy:}

Cells were plated at a density of 50,000/well in 6-well plates on coverslips and allowed to attach overnight. The following day, media was removed and the cells were treated in the absence or presence of GANT61 $(20 \mu \mathrm{M})$ for various times with or without drug washout after $24 \mathrm{hr}$. The coverslips were removed and placed in a humidity chamber for fixation, permeabilization and staining. Images were collected using an HCX P1 Apo $63 \mathrm{X}, 1.4 \mathrm{NA}$ oil immersion objective with Zoom 2 on a Leica SP2 confocal microscope with spectrophotometric detection (Leica Microsystems, GmbH, Wetzlar, Germany). Four-color image acquisition was performed and analysis of images was conducted using Image-Pro Plus software (Media Cybernetics, Inc., Bethesda, MD).

\section{REFERENCE}

1. Katoh Y \& Katoh M Hedgehog target genes: mechanisms of carcinogenesis induced by aberrant hedgehog signaling activation. Curr Mol Med. 2009; 9: 873-886.

2. Yu M. Gipp J, Yoon JW, Iannaccone P, Walterhouse D, Bushman W. Sonic hedgehog-responsive genes in the fetal prostate. J Biol Chem. 2009; 284: 5620-5629.

3. Thiyagarajan S, Bhatia N, Reagan-Shaw S, Cozma D, Thomas-Tikhonenko A, Ahmad N, Spiegelman VS. Role of GLI2 transcription factor in growth and tumorigenicity of prostate cells. Cancer Res. 2007; 67: 10642-10646.

4. Ikram MS, Neill GW, Regl G, Eichberger T, Frischauf AM, Aberger F, Quinn A, Philpott M. GLI2 is expressed in normal human epidermis and BCC and induces GLI1 expression by binding to its promoter. J Invest Dermatol. 2004; 122: 1503-1509.

5. Bai CB, Auerbach W, Lee JS, Stephen D \& Joyner AL. Gli2, but not Gli1, is required for initial Shh signaling and ectopic activation of the Shh pathway. Development. 2002; 129: 4753-4761.

6. Eichberger T, Sander V, Schnidar H, Regl G, Kasper M, Schmid C, Plamberger S, Kaser A, Aberger F, Frischauf AM. Overlapping and distinct transcriptional regulator properties of the GLI1 and GLI2 oncogenes. Genomics. 2006; 87: 616-632.

7. Ruiz IAA, Mas C \& Stecca B. The Gli code: an information nexus regulating cell fate, stemness and cancer. Trends Cell Biol. 2007; 17: 438-447.

8. Mill P, Mo R, Fu H, Grachtchouk M, Kim PC, Dlugosz AA, Hui CC. Sonic hedgehog-dependent activation of Gli2 is essential for embryonic hair follicle development. Genes Dev. 2003; 17: 282-294.

9. Stecca B, Mas C, Clement V, Zbinden M, Correa R, Piguet V, Beermann F, Ruiz I Altaba A. Melanomas require HEDGEHOG-GLI signaling regulated by interactions between GLI1 and the RAS-MEK/AKT pathways. Proc Natl Acad Sci U S A. 2007; 104: 5895-5900.

10. Sanchez P, Hernández AM, Stecca B, Kahler AJ, DeGueme AM, Barrett A, Beyna M, Datta MW, Datta S, Ruiz i Altaba A. Inhibition of prostate cancer proliferation by interference with SONIC HEDGEHOG-GLI1 signaling. Proc Natl Acad Sci U S A. 2004; 101: 12561-12566.

11. Varnat,F, Duquet A, Malerba M, Zbinden M, Mas C, Gervaz P, Ruiz i Altaba A. Human colon cancer epithelial cells harbour active HEDGEHOG-GLI signalling that is essential for tumour growth, recurrence, metastasis and stem cell survival and expansion. EMBO Mol Med. 2009; 1: 338-351.

12. Ecke I, Rosenberger A, Obenauer S, Dullin C, Aberger F, Kimmina S, Schweyer S, Hahn H. Cyclopamine treatment of full-blown Hh/Ptch-associated RMS partially inhibits $\mathrm{Hh} /$ Ptch signaling, but not tumor growth. Mol Carcinog. 2008, 47: 361-372. 
13. Sarangi A, Valadez JG, Rush S, Abel TW, Thompson RC, Cooper MK. Targeted inhibition of the Hedgehog pathway in established malignant glioma xenografts enhances survival. Oncogene. 2009; 28: 3468-3476.

14. Mas C \& Ruiz IAA. Small molecule modulation of HH-GLI signaling: current leads, trials and tribulations. Biochem Pharmacol. 2010; 80: 712-723.

15. Robarge KD, Brunton SA, Castanedo GM, Cui Y, Dina MS, Goldsmith R, Gould SE, Guichert O, Gunzner JL, Halladay J, Jia W, Khojasteh C, Koehler MF, Kotkow K, La H, Lalonde RL, et al. GDC-0449-a potent inhibitor of the hedgehog pathway. Bioorg Med Chem Lett. 2009; 19: 5576-5581.

16. Low JA. \& de Sauvage FJ. Clinical experience with Hedgehog pathway inhibitors. J Clin Oncol. 2010; 28: 5321-5326.

17. De SE, Ferretti E \& Gulino A. Vismodegib, a smallmolecule inhibitor of the hedgehog pathway for the treatment of advanced cancers. Curr Opin Investig Drugs. 2010; 11: 707-718.

18. Lorusso PM, Rudin CM, Reddy JC, Tibes R, Weiss GJ, Borad MJ, Hann CL, Brahmer JR, Chang I, Darbonne WC, Graham RA, Zerivitz KL, Low JA, Von Hoff DD. Phase I Trial of Hedgehog Pathway Inhibitor Vismodegib (GDC0449) in Patients with Refractory, Locally Advanced or Metastatic Solid Tumors. Clin Cancer Res. 2011; 17: 25022511.

19. Von Hoff DD, LoRusso PM, Rudin CM, Reddy JC, Yauch RL, Tibes R, Weiss GJ, Borad MJ, Hann CL, Brahmer JR, Mackey HM, Lum BL, Darbonne WC, Marsters JC Jr, de Sauvage FJ, Low JA. Inhibition of the hedgehog pathway in advanced basal-cell carcinoma. N Engl J Med. 2009; 361: 1164-1172.

20. Dierks C. GDC-0449-targeting the hedgehog signaling pathway. Recent Results Cancer Res. 2010; 184: 235-238.

21. Rudin CM, Hann CL, Laterra J, Yauch RL, Callahan CA, Fu L, Holcomb T, Stinson J, Gould SE, Coleman B, LoRusso PM, Von Hoff DD, de Sauvage FJ, Low JA. Treatment of medulloblastoma with hedgehog pathway inhibitor GDC-0449. N Engl J Med. 2009; 361: 1173-1178.

22. Ji Z, Mei FC, Xie J \& Cheng X. Oncogenic KRAS activates hedgehog signaling pathway in pancreatic cancer cells. J Biol Chem. 2007; 282: 14048-14055.

23. Yauch RL, Dijkgraaf GJ, Alicke B, Januario T, Ahn CP, Holcomb T, Pujara K, Stinson J, Callahan CA, Tang T, Bazan JF, Kan Z, Seshagiri S, Hann CL, Gould SE, Low JA, et al. Smoothened mutation confers resistance to a Hedgehog pathway inhibitor in medulloblastoma. Science. 2009; 326: 572-574.

24. Yoshikawa K, Shimada M, Miyamoto H, Higashijima J, Miyatani T, Nishioka M, Kurita M, Iwata T, Uehara $\mathrm{H}$. Sonic hedgehog relates to colorectal carcinogenesis. J Gastroenterol. 2009; 44: 1113-1117.

25. Bian YH, Huang SH, Yang L, Ma XL, Xie JW, Zhang
HW. Sonic hedgehog-Gli1 pathway in colorectal adenocarcinomas. World J Gastroenterol. 2007; 13: 16591665.

26. Shi T, Mazumdar T, Devecchio J, Duan ZH, Agyeman A, Aziz M, Houghton. cDNA microarray gene expression profiling of hedgehog signaling pathway inhibition in human colon cancer cells. PLoS One. 2010; 5: e13054.

27. Mazumdar T, DeVecchio J, Shi T, Jones J, Agyeman A, Houghton JA. Hedgehog signaling drives cellular survival in human colon carcinoma cells. Cancer Res. 2011; 71: 1092-1102.

28. Frappart PO, Lee Y, Russell HR, Chalhoub N, Wang YD, Orii KE, Zhao J, Kondo N, Baker SJ, McKinnon PJ. Recurrent genomic alterations characterize medulloblastoma arising from DNA double-strand break repair deficiency. Proc Natl Acad Sci U S A. 2009; 106: 1880-1885.

29. Leonard JM, Ye H, Wetmore C \& Karnitz LM. Sonic Hedgehog signaling impairs ionizing radiation-induced checkpoint activation and induces genomic instability. J Cell Biol. 2008; 183: 385-391.

30. Snijders AM, Huey B, Connelly ST, Roy R, Jordan RC, Schmidt BL, Albertson DG. Stromal control of oncogenic traits expressed in response to the overexpression of GLI2, a pleiotropic oncogene. Oncogene 2009; 28, 625-637.

31. Grady WM. Genomic instability and colon cancer. Cancer Metastasis Rev. 2004; 23: 11-27.

32. Mazumdar T, Devecchio J, Agyeman A, Shi T \& Houghton JA. Blocking Hedgehog survival signaling at the level of the GLI genes induces DNA damage and extensive cell death in human colon carcinoma cells. Cancer Res. 2011; 71: 5904-5914.

33. Mazumdar T, DeVecchio J, Agyeman A, Shi T \& Houghton JA. The GLI genes as the molecular switch in disrupting Hedgehog signaling in colon cancer. Oncotarget 2011; 2: 638-645.

34. Schnidar H, Eberl M, Klingler S, Mangelberger D, Kasper M, Hauser-Kronberger C, Regl G, Kroismayr R, Moriggl R, Sibilia M, Aberger F. Epidermal growth factor receptor signaling synergizes with Hedgehog/GLI in oncogenic transformation via activation of the MEK/ERK/JUN pathway. Cancer Res. 2009; 69: 1284-1292.

35. Yoon JW, Kita Y, Frank DJ, Majewski RR, Konicek BA, Nobrega MA, Jacob H, Walterhouse D, Iannaccone P. Gene expression profiling leads to identification of GLI1-binding elements in target genes and a role for multiple downstream pathways in GLI1-induced cell transformation. J Biol Chem. 2002; 277: 5548-5555.

36. Marampon F, Bossi G, Ciccarelli C, Di Rocco A, Sacchi A, Pestell RG, Zani BM. MEK/ERK inhibitor U0126 affects in vitro and in vivo growth of embryonal rhabdomyosarcoma. Mol Cancer Ther. 2009; 8: 543-551.

37. Bedogni B, Welford SM, Kwan AC, Ranger-Moore J, Saboda K, Powell MB. Inhibition of phosphatidylinositol- 
3-kinase and mitogen-activated protein kinase kinase 1/2 prevents melanoma development and promotes melanoma regression in the transgenic TPRas mouse model. Mol Cancer Ther. 2006; 5: 3071-3077.

38. Hinoue T, Weisenberger DJ, Pan F, Campan M, Kim M, Young J, Whitehall VL, Leggett BA, Laird PW. Analysis of the association between CIMP and BRAF in colorectal cancer by DNA methylation profiling. PLoS One. 2009; 4: e8357.

39. Lauth M, Bergstrom A, Shimokawa T \& Toftgard R. Inhibition of GLI-mediated transcription and tumor cell growth by small-molecule antagonists. Proc Natl Acad Sci U S A. 2007; 104: 8455-8460.

40. Ruiz IAA. Gli proteins encode context-dependent positive and negative functions: implications for development and disease. Development. 1999; 126: 3205-3216.

41. Stucki M \& Jackson SP. gammaH2AX and MDC1: anchoring the DNA-damage-response machinery to broken chromosomes. DNA Repair (Amst). 2006; 5: 534-543.

42. Deckbar D, Birraux J, Krempler A, Tchouandong L, Beucher A, Walker S, Stiff T, Jeggo P, Löbrich M. Chromosome breakage after G2 checkpoint release. J Cell Biol. 2007; 176: 749-755.

43. Lobrich M, Shibata A, Beucher A, Fisher A, Ensminger M, Goodarzi AA, Barton O, Jeggo PA. gammaH2AX foci analysis for monitoring DNA double-strand break repair: strengths, limitations and optimization. Cell Cycle. 2010; 9: 662-669.

44. Redon CE, Nakamura AJ, Martin OA, Parekh PR, Weyemi US, Bonner WM. Recent developments in the use of gamma-H2AX as a quantitative DNA double-strand break biomarker. Aging (Albany NY) 2011; 3: 168-174.

45. Nakamura AJ, Rao VA, Pommier Y \& Bonner WM. The complexity of phosphorylated $\mathrm{H} 2 \mathrm{AX}$ foci formation and DNA repair assembly at DNA double-strand breaks. Cell Cycle. 2010; 9: 389-397.

46. Stucki M, Clapperton JA, Mohammad D, Yaffe MB, Smerdon SJ, Jackson SP. MDC1 directly binds phosphorylated histone $\mathrm{H} 2 \mathrm{AX}$ to regulate cellular responses to DNA double-strand breaks. Cell. 2005; 123: 1213-1226.

47. Chapman JR. \& Jackson SP. Phospho-dependent interactions between NBS1 and MDC1 mediate chromatin retention of the MRN complex at sites of DNA damage. EMBO Rep. 2008; 9: 795-801.

48. Canman CE. Checkpoint mediators: relaying signals from DNA strand breaks. Curr Biol. 2003; 13: R488-490.

49. Nojima H. G1 and S-phase checkpoints, chromosome instability, and cancer. Methods Mol Biol. 2004; 280: 3-49.

50. Lim DS, Kim ST, Xu B, Maser RS, Lin J, Petrini JH, Kastan MB. ATM phosphorylates p95/nbs1 in an S-phase checkpoint pathway. Nature. 2000; 404: 613-617.

51. Zhao S, Weng YC, Yuan SS, Lin YT, Hsu HC, Lin SC, Gerbino E, Song MH, Zdzienicka MZ, Gatti RA, Shay JW, Ziv Y, Shiloh Y, Lee EY. Functional link between ataxia- telangiectasia and Nijmegen breakage syndrome gene products. Nature. 2000; 405: 473-477.

52. Bai Y. \& Murnane, J.P. Telomere instability in a human tumor cell line expressing NBS1 with mutations at sites phosphorylated by ATM. Mol Cancer Res. 2003; 1: 10581069.

53. Rossi R, Lidonnici MR., Soza S, Biamonti G \& Montecucco A. The dispersal of replication proteins after Etoposide treatment requires the cooperation of Nbs1 with the ataxia telangiectasia Rad3-related/Chk1 pathway. Cancer Res. 2006; 66: 1675-1683.

54. Olson E, Nievera CJ, Liu E, Lee AY, Chen L, Wu X. The Mre11 complex mediates the S-phase checkpoint through an interaction with replication protein A. Mol Cell Biol. 2007; 27: 6053-6067.

55. Olson E, Nievera CJ, Lee AY, Chen L \& Wu X. The Mre11Rad50-Nbs1 complex acts both upstream and downstream of ataxia telangiectasia mutated and Rad3-related protein (ATR) to regulate the S-phase checkpoint following UV treatment. J Biol Chem. 2007; 282: 22939-22952.

56. Wu L, Luo K, Lou Z \& Chen J. MDC1 regulates intra-Sphase checkpoint by targeting NBS1 to DNA double-strand breaks. Proc Natl Acad Sci U S A. 2008; 105: 11200-11205.

57. Williams GJ, Lees-Miller SP \& Tainer JA. Mre11-Rad50Nbs 1 conformations and the control of sensing, signaling, and effector responses at DNA double-strand breaks. DNA Repair (Amst). 2010; 9: 1299-1306.

58. Neale MJ, Pan J \& Keeney S. Endonucleolytic processing of covalent protein-linked DNA double-strand breaks. Nature. 2005; 436: 1053-1057.

59. Hopfner KP, Karcher A, Craig L, Woo TT, Carney JP, Tainer JA. Structural biochemistry and interaction architecture of the DNA double-strand break repair Mre11 nuclease and Rad50-ATPase. Cell. 2001; 105: 473-485.

60. Bartek J, Lukas C \& Lukas J. Checking on DNA damage in S phase. Nat Rev Mol Cell Biol. 2004; 5: 792-804.

61. Machida YJ, Hamlin JL \& Dutta A. Right place, right time, and only once: replication initiation in metazoans. Cell. 2005; 123: 13-24.

62. Petermann E. \& Caldecott, K.W. Evidence that the ATR/Chk1 pathway maintains normal replication fork progression during unperturbed S phase. Cell Cycle. 2006; 5: 2203-2209.

63. Branzei D \& Foiani M. Interplay of replication checkpoints and repair proteins at stalled replication forks. DNA Repair (Amst). 2007; 6: 994-1003.

64. Uziel T, Lerenthal Y, Moyal L, Andegeko Y, Mittelman L, Shiloh Y. Requirement of the MRN complex for ATM activation by DNA damage. EMBO J. 2003; 22: 5612-5621.

65. Stracker TH, Theunissen JW, Morales M \& Petrini JH. The Mre11 complex and the metabolism of chromosome breaks: the importance of communicating and holding things together. DNA Repair (Amst). 2004; 3: 845-854.

66. Paull TT \& Lee JH. The Mre11/Rad50/Nbs1 complex and 
its role as a DNA double-strand break sensor for ATM. Cell Cycle. 2005; 4: 737-740.

67. Lee JH. \& Paull TT. ATM activation by DNA double-strand breaks through the Mre11-Rad50-Nbs1 complex. Science. 2005; 308: 551-554.

68. Melander F, Bekker-Jensen S, Falck J, Bartek J, Mailand $\mathrm{N}$, Lukas J. Phosphorylation of SDT repeats in the MDC1 $\mathrm{N}$ terminus triggers retention of NBS1 at the DNA damagemodified chromatin. J Cell Biol. 2008; 181: 213-226.

69. Spycher C, Miller ES, Townsend K, Pavic L, Morrice NA, Janscak P, Stewart GS, Stucki M. Constitutive phosphorylation of MDC1 physically links the MRE11RAD50-NBS1 complex to damaged chromatin. J Cell Biol. 2008; 181: 227-240.

70. Dodson GE, Limbo O, Nieto D \& Russell P. Phosphorylation-regulated binding of Ctp1 to Nbs1 is critical for repair of DNA double-strand breaks. Cell Cycle. 2010; 9: 1516-1522.

71. Tillman DM, Izeradjene K, Szucs KS, Douglas L. \& Houghton JA. Rottlerin sensitizes colon carcinoma cells to tumor necrosis factor-related apoptosis-inducing ligandinduced apoptosis via uncoupling of the mitochondria independent of protein kinase C. Cancer Res. 2003; 63: 5118-5125.

72. Drouet J, Delteil C, Lefrançois J, Concannon P, Salles B, Calsou P. DNA-dependent protein kinase and XRCC4DNA ligase IV mobilization in the cell in response to DNA double strand breaks. J Biol Chem. 2005; 280: 7060-7069. 